\title{
Tree Species Diversity and Abundance of Akure Forest Reserve, Ondo State, Nigeria
}

\section{*1OGUNDELE, OM; ${ }^{2}$ IGE, PO; ${ }^{3}$ OWOEYE, YT; ${ }^{1}$ ABANIKANDA, DE; ${ }^{2}$ KOMOLAFE, OO}

\author{
${ }^{*}$ Department of Forestry and Wood Technology, Federal University of Technology Akure, Nigeria. \\ ${ }^{2}$ Department of Social and Environmental Forestry, University of Ibadan, Nigeria \\ ${ }^{3}$ Forestry Research Institute of Nigeria (FRIN), Ibadan. \\ *Corresponding Author E-mail: igepetero@gmail.com; Tel: +2348035826907
}

\begin{abstract}
This study was carried out to examine the tree species diversity and abundance in a natural forest ecosystem in the Southwestern region of Nigeria. Data were collected from a four equal size sampling plot of $50 \times 50 \mathrm{~m}$ in a permanent sample plot section of Akure Forest Reserve. All living trees with $\mathrm{DBH} \geq 10 \mathrm{~cm}$ were measured and identified. A total of 956 trees were encountered. These trees were from 42 genera and 20 families. Celtis zenkeri belonging to the family of Ulmaceae was the species with the highest population distribution while Sterculiaceae was the dominant family in the study area. The Shannon-Wiener Diversity Index $\left(\mathrm{H}^{\prime}\right)$ of 3.196 and species evenness of 0.84 were obtained from the study area. The high values of diversity indices obtained indicated that the forest is rich in biodiversity and hence should be protected from any forms of disturbance to enhance sustainability as well as protect the rare species in it from going into extinction.
\end{abstract}

DOI: https://dx.doi.org/10.4314/jasem.v25i8.20

Copyright: Copyright $(\odot 2021$ Ogundele et al. This is an open access article distributed under the Creative Commons Attribution License (CCL), which permits unrestricted use, distribution, and reproduction in any medium, provided the original work is properly cited.

Dates: Received: 10 May 2021; Revised: 28 June 2021; Accepted: 01 July 2021

Keywords: Tree species diversity, forest reserve, growth, Ulmaceae, sustainability

Forest degradation and deforestation continue to take place at alarming rates, and this has contributed significantly to the current loss of biodiversity (FAO 2020). It has been estimated since 1990 that 420 million hectares of the forested area have been lost through conversion to other land uses, although the rate of deforestation has reduced over the past three decades. The rate of deforestation between 2015 and 2020 has been estimated to 10 million hectares per year, down from 16 million hectares per year in the 1990s and the area of primary forest worldwide has also declined by over 80 million hectares since 1990 (FAO 2020). As reported by Adekunle (2007), the major causes of deforestation include indiscriminate forest exploitation, forest clearance for agriculture, encroachment, and an increase in population. The tropical rainforest located in the southwest and southeast geopolitical zones of Nigeria is very complex and is known for its amazing wealth of plant species because of the favorable climatic condition of the area (Adekunle et al., 2007). Diversity has been defined as the measure of the heterogeneity of a site taking into consideration the number and density of the individual species (Ogunleye et al., 2004). Forests especially those in the tropics serve as stores for biodiversity but subsequent deforestation, fragmentation and degradation destroy the biodiversity as a whole. Also, habitats for wandering species including the endangered ones, are yet to be accounted for. Adekunle (2005), stressed the fact that overexploitation and weakness on law enforcement when it comes to conservation is the major reason for biodiversity loss in Nigeria. In addition, biodiversity assessment is very useful in evaluating the rate of forest depletion in our forest reserves to know the effect of various land use activities and curb the threat. (Hastrup et al., 2019). Illegitimate removal of trees in the forest causes an increase in global warming and shortages of wood for the wood-based industries and reducing the standard of living of the people. Therefore this called for inventory practices to know the abundance and diversities of forest trees for conservation purposes. Hence this study was carried out in the Akure Forest Reserve, Ondo State, Nigeria to know the status of the forest reserve in terms of species diversities and abundance.

\section{MATERIALS AND METHODS}

The Study Area: This study was carried out in the Akure Forest Reserve Ondo State, Nigeria (Fig 1). It covers an area of about 32 hectares (Adeduntan and Olusola 2013). It is geographically located in a humid rainforest zone of Akure South Local government area of Ondo State, Nigeria. It lies between latitudes $7^{\circ} 16^{\prime}$ 
and $7^{\circ} 18^{\prime} \mathrm{N}$ of the Equator and longitudes $5^{\circ} 9^{\prime}$ and $5^{\circ} 11^{\prime} \mathrm{E}$ of the Greenwich Meridian. (Adelakun and Adeoye 2019). Akure forest reserve has a tropical climate with prominent wet and dry seasons: the rainy season and the dry season. The rainy season generally occurs between March and October while the dry season occurs between November and February yearly. Also, the mean annual temperature is about $26^{\circ} \mathrm{C}$ (minimum $19^{\circ} \mathrm{C}$ and maximum $34^{\circ} \mathrm{C}$ ) (Adekunle et al., 2013).

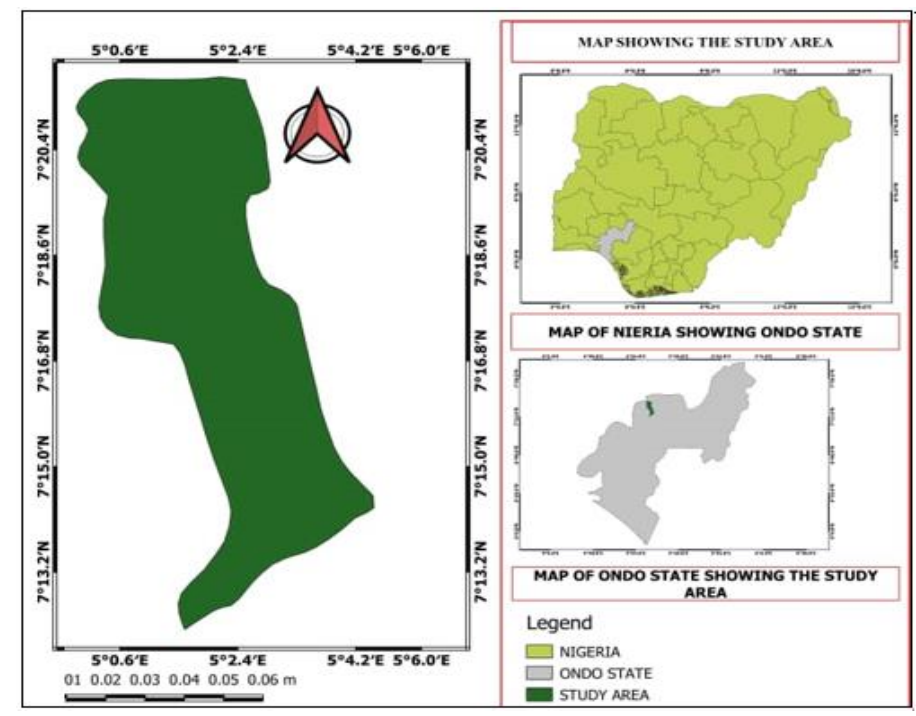

Fig 1: Map of the study area

Method of Data Collection: Four equal size sampling plots were selected $(50 \mathrm{x} 50 \mathrm{~m})$ by adopting the systematic line transect method. All living trees with the $\mathrm{Dbh} \geq 10 \mathrm{~cm}$ in each plot were enumerated. Their Diameter at breast height (Dbh), Diameter at the base (Db), Diameter at the middle (Dm), Diameter at the top (Dt) and height (Ht) were measured using appropriate equipment. The botanical name of every tree encountered in each sample plot were recorded in the study site. Where a tree's botanical name is not known straightaway, such trees were identified by their commercial or local names and were later translated to correct botanical names. Gbile (1984) and Keay (1989).

Data Analysis: Basal area: The basal area of each tree in the sample plot was estimated using the formula:

$$
\mathrm{BA}=\frac{\pi D^{2}}{4} \ldots \ldots(1)
$$

Where BA $=$ Basal Area $\left(\mathrm{m}^{2}\right), \mathrm{D}=$ Diameter at breast height $(\mathrm{cm})$ and $\pi=$ pie (3.142).

The total basal area for each of the sample plots was obtained by the sum of the BA of all trees in the plot Basal area per hectare was obtained by multiplying mean basal per plot with the number of $50 \times 50 \mathrm{~m}$ plots in a hectare.

$$
\mathrm{BA}_{\mathrm{ha}}=\mathrm{BA}_{\mathrm{P}} \mathrm{X} 4
$$

Where $\mathrm{BA}_{\text {ha }}=$ basal area per hectare

Volume: The volume of an individual tree was estimated using Newton's equation developed for trees volume estimation in the rainforest ecosystem. This equation is expressed as follows

$$
\left.\mathrm{V}=\pi H \frac{\left(D_{b}^{2}+4 D_{m}^{2}+D_{t}^{2}\right.}{24}\right) \ldots \ldots \ldots
$$

Where $\mathrm{V}=$ Volume of tree $\left(\mathrm{m}^{3}\right), \mathrm{Ht}=$ Height; $\mathrm{D}^{2} \mathrm{~b}=$ Diameter at the base, $\mathrm{D}^{2} \mathrm{~m}=$ Diameter at the middle, $\mathrm{D}^{2} \mathrm{t}=$ Diameter at the top, $\pi=$ Pie (3.142)

Total Plot Volume was obtained by adding the volume of individual trees encountered in the plots. Mean volume for sample plots was calculated by dividing the total plot by the number of sampling plots (4). Volume per hectare was obtained by multiplying mean volume per plot $V_{P}$ with the number of $50 \times 50 \mathrm{~m}$ plots in a hectare.

$$
\mathrm{V}_{\mathrm{ha}}=\mathrm{V}_{\mathrm{P}} \mathrm{X} 16
$$

Tree species classification and diversity indices: All trees were assigned to families and number of species in each family was obtained for tree species diversity classification. Frequency of occurrence was obtained for species abundance or richness. The following biodiversity indices were used to obtain tree species: richness and evenness within the forest. Species 
relative density (RD) was obtained using the formula given by Oduwaiye et al. (2002):

$$
R D=\frac{n_{i}}{N} \times 10
$$

Where $\mathrm{RD}=$ relative density, $\mathrm{n}_{\mathrm{i}}=$ number of individuals of species $\mathrm{i}$ and $\mathrm{N}=$ total number of individuals in the entire population.

Relative dominance was obtained using the formula given by Brashears et al. (2004):

$$
\mathrm{RD}_{\mathrm{O}}=\frac{\sum B A i x 100}{\sum B A n}
$$

Where $\mathrm{RD}_{0}=$ relative dominance, $\mathrm{BA}_{\mathrm{i}}=$ basal area of all individual trees belonging to a particular species $\mathrm{i}$ and $\mathrm{BA}_{\mathrm{n}}=$ stand basal area.

Tree diversity was obtained using a mathematical formula that takes into account the species richness and abundance of each tree. The equation for the Shannon- Wiener diversity index given by Price (1997) that was used is:

$$
\mathrm{H}^{1}=\sum_{i=1}^{s} p_{i} \operatorname{Lnp}_{i} \ldots \ldots(7)
$$

$\mathrm{H}^{1}$ is the Shannon diversity index, $\mathrm{S}$ is the total number of species in the sample plot, $p_{i}$ is the proportion of a species to the total number of plants in the sample plots and $\mathrm{Ln}$ is the natural logarithm.

Species evenness (E) in each of the plots was determined using Shannon's equitability $\left(\mathrm{E}_{\mathrm{H}}\right)$ as stated by Kent and Coker (1992):

$$
E=\frac{H^{1}}{\operatorname{Ln}(S)}
$$

$\mathrm{S}$ is the total number of species in each plot

\section{RESULT AND DISCUSSION}

The results of this study showed the level of plant species diversity, richness and distribution in a typical tropical rainforest ecosystem in southwestern Nigeria.

Summary of Tree Growth Variables in the study area: Table 1 revealed the summary of the tree growth variables encountered in the study area. 42 different species making a total of 239 individual tree species from 20 families were encountered in the demarcated plots. The values got for mean Dbh, mean height, basal area/ha and volume/ha were $63.69 \mathrm{~cm}, 13.59 \mathrm{~m}, 0.47 \mathrm{~m}^{2}$ and $3.02 \mathrm{~m}^{3}$ respectively.

Table 1: Summary of Tree Growth Variables in the study area

\begin{tabular}{ll}
\hline No of spp & 42 \\
No per sample plot & 239 \\
Mean DBH $(\mathrm{cm})$ & 63.69 \\
Mean Height $(\mathrm{m})$ & 13.59 \\
Basal Area $\left(\mathrm{m}^{2}\right)$ & 0.47 \\
Volume $\left(\mathrm{m}^{2}\right)$ & 3.02 \\
\hline
\end{tabular}

Tree Species Diversity and Abundance: The tree species diversity and abundance in the study area are presented in Table 2. Based on the result a total number of two hundred and thirty-nine (239) individual trees were recorded with 42 genera from 20 different families were identified in the study area.

\begin{tabular}{|c|c|}
\hline Biodiversity Indices & Values \\
\hline No. of Individual ha ${ }^{-1}$ & 956 \\
\hline No. of Species & 239 \\
\hline No of Genera & 42 \\
\hline No of Family & 20 \\
\hline Shannon Diversity Index & 3.18 \\
\hline Evenness & 0.84 \\
\hline
\end{tabular}
Shannon-weiner index of diversity $\left(\mathrm{H}^{\prime}\right)$ and species evenness had values of 3.18 and 0.84 respectively.

Table 2. Tree Species Diversity and Abundance in the Study Area

Family distribution of tree species in the Study Area: Table 3 shows that the family sterculiaceae has the highest number of species (6 different species), followed by Malvaceae family (4). Single tree species/family were recorded for Boraginaceae, Caesalpinioidae, Cecropiaceae, Ebenaceae, Euphorbiaceae, Olacaceae, Papilionaceae and Sapindaceae families. For species abundance/ha, Sterculiaceae family has the highest value of 208 followed by Ulmaceae (172) and next to it is Apocynaceae (120) while the least (8) species abundance/ha was recorded for Caesalpinioidae, Cecropiaceae, Papilionaceae and Sapindaceae.

Table 3: Family distribution of tree species in the study area

\begin{tabular}{lll}
\hline FAMILY & $\begin{array}{l}\text { No of SPP/ } \\
\text { Family }\end{array}$ & $\begin{array}{l}\text { Species } \\
\text { Abundance }\end{array}$ \\
\hline Annonaceae & 2 & 24 \\
Apocynaceae & 2 & 120 \\
Asteraceae & 3 & 12 \\
Boraginaceae & 1 & 40 \\
Caegalpinioidae & 1 & 8 \\
Cannabaceae & 2 & 44 \\
Capparaceae & 3 & 48 \\
Cecropiaceae & 1 & 8 \\
Ebenaceae & 1 & 12 \\
Euphorbiaceae & 1 & 20 \\
Leguminosae & 2 & 20 \\
Malvaceae & 4 & 68 \\
Meliaceae & 3 & 24 \\
Moraceae & 2 & 48 \\
Olacaceae & 1 & 24 \\
Papilionaceae & 1 & 8 \\
Rubiaceae & 2 & 40 \\
Sapindaceae & 1 & 8 \\
Sterculiaceae & 6 & 208 \\
Ulmaceae & 3 & 172 \\
Total & 42 & 956 \\
\hline
\end{tabular}


Diversity and Relative Dominance of families encountered in the study area: The result of the relative dominance is shown in Table 4. Sterculiaceae family has the relative dominant value of 20.82, next to it is Apocynaceae (20.16) followed by Boraginaceae (12.06) while the least of all the family is Ulmaceae (0.12). Sterculiaceae has the highest number of species (6).

All the family species encountered in the entire plot were: Annonaceae, Apocynaceae, Asteraceae, Boraginaceae, Caesalpinioidae, Cannabaceae, Capparaceae, Cecropiaceae, Ebenaceae, Euphorbiaceae, Leguminosae, Malvaceae, Meliaceae, Moraceae, Olacaceae, Papilionaceae, Rubiaceae, Sapindaceae, Sterculiaceae, Ulmaceae.

\begin{tabular}{|c|c|c|c|}
\hline S/N & FAMIIY & $\begin{array}{l}\text { No of SPP/ } \\
\text { Family }\end{array}$ & Rdo \\
\hline 1 & Annonaceas & 2 & 1.54 \\
\hline 2 & Apocynaceae & 2 & 20.16 \\
\hline 3 & Asteraceae & 3 & 1.28 \\
\hline 4 & Boraginaceas & 1 & 12.06 \\
\hline 5 & Caesalpinioidae & 1 & 0.85 \\
\hline 6 & Cannabaceas & 2 & 2.67 \\
\hline 7 & Capparaceas & 3 & 2.15 \\
\hline 8 & Cecropiaceae & 1 & 0.13 \\
\hline 9 & Ebenaceae & 1 & 0.95 \\
\hline 10 & Euphorbiaceas & 1 & 1.78 \\
\hline 11 & Loguminosae & 2 & 0.62 \\
\hline 12 & Malvaceas & 4 & 4.54 \\
\hline 13 & Meliaceas & 3 & 1.17 \\
\hline 14 & Moraceae & 2 & 8.26 \\
\hline 15 & Olacaceas & 1 & 5.38 \\
\hline 16 & Papilionaceas & 1 & 0.38 \\
\hline 17 & Rubiaceae & 2 & 2.39 \\
\hline 18 & Sapindaceae & 1 & 1.46 \\
\hline 19 & Sterculiaceae & 6 & 20.82 \\
\hline 20 & Ulmaceas & 3 & 0.12 \\
\hline
\end{tabular}

This study revealed the level of plant species diversity, richness and abundance in the Akure forest reserve. A total number of nine hundred and fifty-six (956) individual trees were recorded; forty-two tree species were identified in the study area and were distributed in twenty (20) families. Sterculiaceae, Apocynaceae, and Baraginaceae were the most dominating families, this shows that the study area is rich in plants species. Hence, the presence of numerous tree species on a stand not only aids the conservation of more trees but other organisms as well (Amonum et al., 2019). The result of this study showed that the Sterculiaceae family has the highest dominant value of 20.82 with a total of 208 species and this is similar to the result of Adekunle et al. (2013) where Sterculiaceae was the highest dominant value with 32.84 .
However, Celtis zenkeri, Mansonia altissima, and Sterculia rhinopetala were observed to have higher value indices than the rest of the species observed. This finding is in agreement with the result of Adekunle et al. (2013) on these species. This could indicate that the conservation measures given to the forest favored these species to dominate the forest compared to other species with lower importance value (Omomoh et al., 2019). The species diversity obtained in the study site when assessed with the Shannon-Weiner $\left(\mathrm{H}^{\prime}\right)$ index was found to be 3.18. This result obtained indicated a high tree species diversity as stated by Magurran (2004) that a low $\mathrm{H}^{\prime}$ value usually suggests a site with few species and a few dominant species, while a high $\mathrm{H}^{\prime}$ value suggests considerably more species. (Amonum et.al 2019). This result is similar to that reported by Adekunle et al. (2013) who obtained 3.74 Shannon-Weiner Index (H') for a Nigerian strict nature reserve.

Conclusion: The results obtained from this study shows that the forest reserve lot of different biodiversity of which the occurrence of some of its tree species are higher than others, this biodiversity makes this forest home of forest tree species that require enhanced conservation and management efforts to promote forest sustainability, on the other hand, some of the species are rare, To protect these rare species of trees, conservation efforts should be enhanced to protect them from going into extinction. Therefore, knowing the species diversity and abundance of this forest helps to know its status in terms of trees species distribution and availability. Therefore to conserve and protect this forest, there should be adequate monitoring of the forest reserve from any form of human activities such as deforestation, farming and hunting.

\section{REFERENCES}

Adeduntan S.A and Olusola J.A (2013). Diversity and Abundance of Arthropods and Tree Species as Influenced by Different Forest Vegetation types in Ondo State, Nigeria. Inter. J. Ecosystem 3(3): 19-23.

Adekunle V. A. J. (2005). Trend in Forest Reservation and Biodiversity Conservation in Nigeria. In: Environmental Sustainability and Conservation in Nigeria. - In: Environmental Sustainability and Conservation in Nigeria, Okoko, E., Adekunle, V.A.J. \&Adeduntan, S.A. (editors) Environmental Conservation and research Team, Federal University of Technology, Akure Nigeria, pp 82-90. 
Adekunle, V.A.J. (2007). Ecological and environmental implications of national development: A case study of Obanla natural forest, Federal University of Technology, Akure, Nigeria. Res. J. Environ. Sci. 1:127- 690140.

Adekunle V.A.J and Fatade T (2007). Trade and utilization of useful Medicinal Plants from Tropical Forest Ecosystem in Ondo State. In: Onibi GE, Agele SO, Adekunle VAJ \& Akinbulumo MO (eds) Medicinal plants in agriculture: the Nigerian experience. Proceedings of the third Annual Conference of the School of Agriculture and Agricultural Technology, Federal University of Technology, Akure, Nigeria/ Humboldt Kellong held on $14^{\text {th }}$ to $19^{\text {th }}$ April, 2007. pp. 291-297.

Adekunle V.A.J., A.O. Olagoke and S.O. Akindele. (2013). Tree species diversity and structure of a Nigerian Strict nature reserve. Inter. Soc. Tropical Ecol. 54(3): 275-289

Adelakun, Gbiri and Adeoye, Nathaniel. (2019). Analysis of Pattern and Extent of Deforestation in Akure Forest Reserve, Ondo State, Nigeria. J. Environ. Geog.. 12. 1-11

Amonum, J.I., Jonathan, B.A., and Japheth, H.D. (2019). 'Structure and Diversity of Tree Species at the College of Forestry and Fisheries, University of Agriculture Makurdi, Benue State, Nigeria. Inter. J. For. Horticulture 5(1). 20-27

Brashears, M. B., M. A. Fajvan and T. M. Schuler. (2004). An assessment of canopy stratification and tree species diversity following clearcutting in central Appalachian hardwoods. Forest Science 50: $54-64$.

FAO (2020). The state of the world's forest 2020. Pp 9-10
Fasinmirin J.T and Oguntuase A.M (2008). Soil moisture distribution pattern in Amaranthus cruentus field under drip irrigation system. Afr. J. Agric. Res. 3(7): 486-493.

Gbile Z.O (1984). Vernacular names of Nigerian Plants-Yoruba. Forestry Research Institute of Nigeria, Ibadan, Nigeria. Pp. 87.

Haastrup N.O, Dahunsi O.M, and Baba G.O (2019). 'Diversity and Abundance of Tree Species at Owo Forest Reserve. International Journal of Research and Innovation in Applied Science pp. 27-32.

Keay, R.W.J. (1989). Trees of Nigeria. Clarendon Press, Oxford, UK.

Kent, M., and Coker, P. (1992). Vegetation Description and Analysis: A Practical Approach pp. 167-169. New York: John Wiley and Sons.

Magurran, A.E. (2004). Measuring Biological Diversity. Blackwell Publishing, Oxford, Pp 256

Oduwaiye E.A., and Ajibode, M.O., (2005). Composition of tree species and regeneration potential at Onigambari Forest Reserve, Ibadan, Oyo State, Nigeria. J. Raw Mat. Res. 2 (1):4-13

Ogunleye, A.J., Adeola, A.O., Ojo, L.O. and Aduradola, A.M.,(2004). Impact of Farming Activities on Vegetation in Olokemeji Forest Reserve, Nigeria. Global Nest: The International J. 6. 2. $131-140$.

Ojo, L.O. (1991). Application of Multi-species matrix models in stand projection. A case study of the Nigerian Moist Tropical Forest. Nig. J. Fore. 21(2): 55-67.

Price, P.W. (1997). Insect ecology. 3rd Edition, John Wiley \& Sons, Inc., New York. 